\section{KENNETH J. ARROW ÉS A BIZTOSÍTÁSOK}

Dócs Kristóf, docs.kristof@heller.uni-corvinus.hu

\section{KÖSZÖNETNYILVÁNÍTÁS}

Szeretném kinyilvánítani hálámat és köszönetemet Pandurics Anettnek a téma felvetéséért és a folyamatos támogatásért, illetve Kovács Erzsébetnek és Ágoston Kolosnak a feldolgozandó irodalom kijelölésében nyújtott segítségükért.

\section{ÖSSZEFOGLALÓ}

A cikkben Kenneth J. Arrow három biztosítási relevanciával rendelkező írásába nyerhet betekintést az olvasó. Az elsőben bemutatásra kerülnek az egészségügy azon különleges tulajdonságai, amelyek gátolják egy hatékony piac kialakulását. A második bemutatásra kerülő cikk Arrow reflexióit tartalmazza az előző írást ért kritikákat illetően, illetve több évtizedes távlatból értékeli eredeti megállapításait. A harmadik cikk pedig az optimális biztosítási struktúrát vizsgálja mikroökonómiai szempontból, és jut általános érvényű következtetésekre a bizonytalanság melletti döntésekkel kapcsolatban.

\section{SUMMARY}

This article provides an insight to the insurance related works of Kenneth J. Arrow. The first study cited describes the unique properties of the medical care market that prevent the emergence of a competitive market. The second article includes Arrow's reflections on the critiques emerged regarding the first publication. The third study is about the optimal insurance policy from a microeconomic standpoint that provides a general conclusion on decisions under uncertainty.

Kulcsszavak: egészségügyi piac, egészségbiztosítás

Keywords: Health Care Market, Health Insurance

JEL: I11, I13

DOI: $10.18530 /$ BK.2017.2.10

http://dx.doi.org/1018530/BK.2017.2.10

\section{Bevezetés}

Kenneth J. Arrow, a 20. század egyik legkiemelkedőbb közgazdásza 2017. február 21én, 95 éves korában halt meg. Azóta méltató cikkek sora jelent meg szakmai és közéleti folyóiratokban, ezt fogja bővíteni az alábbi írás is, amely Arrow szerteágazó életművének egy kisebb szeletét mutatja be, mely biztosítási relevanciával rendelkezik.

Egyik cikk sem felejti el megemlíteni, hogy mindmáig ő a legfiatalabb Nobel-emlékdíjas közgazdász, és tanítványai közül is többen részesültek az elismerésben. Tanulmányait a City College of New Yorkban kezdte meg társadalomtudományi területen, de mesterfokozatot már a Columbia Egyetemen szerzett matematikából, és ekkor kezdett a matematikai közgazdaságtannal foglalkozni. Pályája 1949-től kezdve a Stanfordhoz kötötte egy 11 éves harvardi kitérő kivételével. Sokat foglalkozott a jóléti közgazdaságtan kérdéseivel, és az áttörést jelentő sikert az Arrow-féle lehetetlenségi tétellel érte el, amellyel megmutatta, hogy nem létezhet olyan általános szabály, amely az egyéni preferenciák minden kombinációján működik, független az irreleváns választási lehetőségektől, teljesíti a Pareto-feltételt és nem diktatórikus egyszerre (Csekő, 2017).

Másik fö eredménye az általános egyensúlyelmélet egzisztenciatételének bizonyítása, miszerint egy hatékony piacon az elkülönült, a saját egyéni érdeküket követő gazdasági szereplők cselekedetei nem káoszhoz, hanem szükségszerűen egy konzisztens, koordináltnak tűnő állapothoz vezetnek. Az említett két területen elért eredményei elismeréséül kapta meg 1972-ben John Hicksszel megosztva a közgazdasági Nobel-emlékdíjat. Munkássága viszont rendkívül kiterjedt volt, a közgazdaságtan legkülönbözőbb területeit fedte le. Maradandót alkotott az egyensúlyelmélet dinamizálását illetően, illetve a bizonytalanság melletti döntések területén. Megalapozta az endogén növekedés elméletét a termeléssel szerzett tudás fogalmának bevezetésével, és a teljes informáltság feltételének feloldásával útjára indította az információ közgazdaságtanát (Csekő, 2017).

Sokat elmond Arrow széles körű érdeklődéséről az az anekdota, amelyet a szintén Nobel-emlékdíjjal kitüntetett közgazdász, Eric Maskin osztott meg a szélesebb közönséggel. Fiatalabb kollégái egyszer úgy akartak túljárni Arrow eszén, hogy némi felkészülés után a szürke bálnák szaporodási szokásairól kezdtek beszélgetni Arrow felbukkanására várva. Arra számítottak, hogy végre egyszer lesz egy téma, amelyben professzoruk nem tudja kijavítani őket. Amikor Arrow felbukkant, éppen egy Turner nevű kutató elméletét vitatták meg azt illetően, hogy a szürke bálnák hogyan találják meg minden évben a párzási helyüket. Az ifjú kutatók egy ideig azt hitték, hogy tervük sikerrel járt, majd a távozó Arrow csak annyit motyogott maga elé: „Pedig azt hittem, Turner elméletét már teljesen cáfolta Spencer, és igazolta, hogy az említett mechanizmus nem működhet." (Weinstein, 2017)

Ebből a bevezetőből is látszik, milyen szerteágazó volt Arrow érdeklődési köre, illetve a munkássága által lefedett terület. Ebben az írásban Arrow három biztosítási relevanciával bíró cikke kerül bemutatásra. Az első az 1963-ban kiadott Uncertainty and the Welfare 
Economics of Medical Care címü cikke, melyet többen az egészségügy közgazdaságtanának egyik alapműveként tartanak számon. Ebben bemutatásra kerülnek az egészségügy azon különleges tulajdonságai, melyek gátolják egy hatékony piac kialakulását. A második bemutatásra kerülő cikk Arrow reflexióit tartalmazza az előző cikket ért kritikákat illetően, illetve több évtizedes távlatból értékeli eredeti megállapításait. A harmadik cikk pedig az optimális biztosítási struktúrát vizsgálja mikroökonómiai szempontból, és jut általános érvényű következtetésekre. Arrow teljes munkásságát egyetlen cikkben bemutatni teljes képtelenség, de még csak a biztosításokhoz kapcsolódóan is kár megpróbálkozni vele, ez a három cikk éppen csak bepillantást enged a 20. század egyik nagy gondolkodójának munkásságába.

\section{Arrow cikke az egészségügy piacáról ${ }^{1}$}

Kenneth J. Arrow egyik legjelentősebb cikke, amely biztosítási relevanciával is bír, 1963-ban jelent meg a The American Economic Review hasábjain Uncertainty and the Welfare Economics of Medical Care címen. Ebben a cikkben bonyolultabb modellek felállítása nélkül próbálja bemutatni, hogy az egészségügyi szolgáltatások területén miért nem alakul ki hatékony piac, és ezt elsősorban a szolgáltatáshoz kapcsolható bizonytalansággal indokolja.

Az elején érdemes tisztázni, hogy pontosan milyen szolgáltatásokról van szó, a fordítás ugyanis megtévesztő lehet. A cikk angolul a „medical care” kifejezést használja, amit magyarul leginkább az egészségügy szóval jelölhetnénk, de Arrow külön kiemeli, hogy ez alatt ő nem az egész „health care” iparágat érti, mert abba szerinte az egészséges táplálkozástól kezdve sokkal több terület beletartozik, ő kifejezetten csak az orvosok által végzett orvosi szolgáltatásokat, illetve az ezekhez kapcsolódó kiegészítő szolgáltatásokat érti bele. Mivel ezekre a szolgáltatásokra magyarul többnyire egészségügy néven hivatkozunk, ezt a kifejezést használom a továbbiakban.

\section{Az egészségügyi szolgáltatások területén \\ nem alakul ki hatékony piac.}

A cikk fö állítása tehát, hogy az egészségügyi szolgáltatások piacán nem tud hatékony piac kialakulni, a hatékony piacokkal rendelkező iparágaktól szignifikánsan eltér az egészségügy. Egy hatékony piac mindig egy optimális egyensúlyi pontba tart, és ez az egyensúlyi pont a kezdeti vagyoneloszlás függvénye. Arrow szerint ennek a kezdeti vagyonelosztásnak a helyettesítői az adók és állami támogatások, ugyanis ezek is a társadalom vagyoneloszlását allokálják újra, bár bizonyos szempontból biztosításként is felfoghatóak. Alapvetően a társadalom szerencsésebb helyzetben lévő tagjai fizetik az adókat, míg a kevésbé szerencsések részesednek a támogatásokból.

\section{Az egészségügy különleges tulajdonságai}

A bevezető részt követően Arrow végigveszi az egészségügyi szolgáltatások piacának azon tulajdonságait, amelyek szerinte megakadályozzák a hatékony piac kialakulását. A legtöbb ilyen tulajdonságot érzékletes példákon keresztül mutatja be, illetve össze is veti más, hatékony piacokkal.

Az első ilyen tulajdonság az igények nem rendszeresen felmerülő és előre nehezen becsülhető mivolta az egyén szintjén. Egyénileg nem lehet tervezni az orvosi szolgáltatások igénybevételének idejével vagy mértékével, a betegségek vagy balesetek, melyek létrehozzák az igényt, váratlanul következnek be. Az ilyen jellegü igényekre lehet biztosítást kötni, de itt annyival is bonyolultabb a helyzet, hogy a veszteségek egy része egyszerüen biztosíthatatlan. Az orvosi szolgáltatások költségét még meg lehet téríteni egy biztosítással, sőt akár a lábadozás alatt kiesett nyereséget is, de az elszenvedett kényelmetlenség vagy a maradandó egészségkárosodás már nem kompenzálható.

A következő különleges tulajdonság a kínálati oldalt jellemzi. Ebben az 1963-as cikkben még kérdés nélkül amellett áll ki Arrow, hogy az orvosok piaci viselkedése nem összevethetö az üzletemberekével. Amíg más piacokon az üzletemberek elsődleges célja mindenképp a profitmaximalizálás, addig egy orvos elsődleges célja a gyógyítás, és a kezelést a beteg igényei szabják meg, nem pénzügyi szempontok. Az orvos nem végez keresztértékesítést, tehát nem beszéli rá további szolgáltatásainak az igénybevételére a betegeit profit céljából, illetve reklámok sincsenek.

Maga a termék is különleges, ugyanis előre nem megismerhető. Amikor a kezelés elkezdődik, a páciens, azaz a fogyasztó nem tudhatja még, hogy mit kap, hatásos lesz-e a kezelés vagy sem. Ehhez jön még egy hatalmas információs aszimmetria is, ugyanis az orvos sokkal mélyebb tudással rendelkezik a helyzettel kapcsolatban, mint a beteg, aki így ki van szolgáltatva az orvos tudásának. A termék ezen tulajdonsága hatalmas mértékủ bizalmat tesz szükségessé a piacon, amit szintén nehéz közgazdasági modellekkel értelmezni.

A kínálat mindemellett igen rugalmatlan. A piacon jelen lévő orvosok száma lassan változik, ugyanis az egyetemi képzésre nehéz bekerülni és elvégezni, továbbá sokáig is tart. Az orvosi diploma megszerzése után pedig a kamara is folyamatosan felügyeli a tevékenységüket, és akár meg is vonhatja az engedélyüket, a kereslet változásait tehát nagyon lassan tudja csak lekövetni a kínálat.

Az Arrow által említett utolsó terület az árazásra vonatkozik, amely viszont eléggé országspecifikus, írásában az Amerikai Egyesült Államokra koncentrál. Teljesen legálisan müködik a piacon az árdiszkrimináció, ugyanis az orvosok etikai alapon akár ingyen is ellátnak betegeket, illetve a kamara által javasolt árak kartellnek tekinthetőek.

A cikk keletkezése óta már az amerikai rendszer is sokat változott, így árazás tekintetében az érvek kevésbé erősek, azok nem hosszú távon határozzák meg a piacot, de a többi jellemző, melyet Arrow felsorolt, mind a mai napig meghatározza a piacot minden országban. 


\section{Az egészségügyi piac egyedi tulajdonságainak gyakorlati implikációi}

A cikk második felében Arrow bemutatja, hogy az eddig felsorolt egyedi tulajdonságok milyen jelenségeket implikálnak a piacon. Ezt az elméleti, tökéletes biztosítás bemutatásával kezdi. Felteszi, hogy minden piaci szereplő racionális, és maximalizálja a hasznosságát, továbbá a fogyasztók kockázatkerülőek, tehát ha választhatnak egy biztos $m$ összeg és egy bizonytalan, de $m$ várható értékkel rendelkező összeg között, akkor mindenképpen a biztos kimenetelt választják.

A biztosítók ezzel szemben egy $m$ várható értékủ veszteségre már $m$ díjért cserébe hajlandóak biztosítást nyújtani, és ezért kialakul egy megegyezési tartomány a fogyasztók és a biztosítók között, ahol a tranzakciók egyértelmüen növelik a társadalmi jólétet, tehát értékteremtés történik

Ettől a tökéletes, ám elméleti világtól viszont több szempontból is eltér a valóság. Felmerül például a morális kockázat kérdése. Egy tökéletes biztosítást csak olyan eseményre lehetne kötni, ahol a biztosított nincs hatással a biztosítási eseményre, de ahogy egy lakásbiztosításnál is felmerülhet, hogy a biztosított kevésbé figyel a konyhai tűz megakadályozására, úgy az egészségbiztosításnál is lehet, hogy a biztosított kevésbé fog az egészséges életmódjára gondot fordítani, és akkor a direkt biztosítási csalásra még ki sem tértünk.

Arrow szerint empirikusan is megfigyelhető, hogy ahol elterjedtebb az egészségbiztosítás, ott nagyobb az igény az orvosi szolgáltatások iránt, és szerinte ez erre a morális kockázatra vezethető vissza. Ezt igazolja, hogy a mütétek és hasonlóan fontos beavatkozások esetében már kisebb a különbség, ezeket kevésbé befolyásolja a biztosítottak hanyagsága.

A tökéletes elméleti állapotot tovább gyengíti a külső kontroll hiánya. Ha nem olyan biztosítás védi a pácienst, amely egy kórházhoz köti, betegség esetén nem lesz motivált a jó ár-érték arányú szolgáltatás igénybevételében, sok ilyen páciens esetében pedig a kórházak sem érdekeltek a költségcsökkentésben.

Minden kockázat különböző, de a biztosítók igyekeznek sztenderdizált terméket kínálni.

A tökéletes biztosításnál Arrow azzal az elrugaszkodott feltételezéssel élt, hogy egy $m$ várható értékű eseményre már $m$ díjért is kötne biztosítást a biztosító, de a valóságban a díjnak a biztosító működését is feltétlenül fedeznie kell, ami viszont már nem biztos, hogy hagy megegyezési tartományt az ügyfelek és a biztosítók között. Ezen felül, mivel minden kockázat különböző, mindegyikre különböző termék volna fair, de éppen az említett adminisztrációs költségek nyomása miatt a biztosítók igyekeznek minél több kockázatot és minél többfajta ügyfelet egy kalap alá venni és nekik sztenderdizált terméket kínálni.

Mivel a kezelés kimenetele is bizonytalan, ha rendelkezik is biztosítással a páciens, nem tudhatja, hogy az tényleg segíti-e a felépülését. A tökéletes biztosítás tehát azt is kompenzálná, ha hatástalan lenne az orvosi beavatkozás, de mivel az életminőség csökkenését nehéz pénzzel kompenzálni, Arrow szerint hasonló hatással lenne a piacra, ha ilyenkor nem kapna az orvos fizetséget a munkájáért, ám természetesen ez sem jellemző a valóságban.

Az aszimmetrikus információs felállás pedig tovább erősíti a bizalom szerepét a piacon. Az orvosnak sokkal jobb információi vannak a kezelés kimeneteiröl, mint a betegnek, így az kénytelen megbízni az orvos javaslataiban, és Arrow szerint ez a bizonytalansági tényező a legfontosabb a piac meghatározásában.

A bizonytalanság leküzdésére léteznek nagyon szigorú és nehezen elvégezhető orvosi képzések, és ezek a bizonyítványok, bár komoly belépési korlátot jelentenek, és ezzel rugalmatlanná teszik a kínálatot, hatékonyan csökkentik a bizonytalanságot is. Pontosan ugyanez az oka annak is, hogy az orvosok nem profitmaximalizáló magatartást folytatnak, hiszen az is ezt a mély bizalmi kapcsolatot ásná alá

\section{A bizonytalanság gyengíti a piac hatékonyságát.}

A cikkben tehát Arrow összefoglalta legfontosabb érveit arra vonatkozóan, hogy miért nem tud kialakulni hatékony piac az egészségügy területén. Megemlíti, hogy hasonló piaci súrlódások máshol is megfigyelhetőek, de ebben az esetben a leglátványosabb az eltérés a hatékony piacoktól, ráadásul a súrlódásokat okozó társadalmi intézmények megléte a piaci szereplők javát szolgálja. Arrow szerint a jelenség gyökere a bizonytalanságban rejlik, és emiatt van szükség a szigorú képzésre, a bizonyítványokra, a kamarára és a nem feltétlenül profitmaximalizáló magatartásra, amelyek mind gyengítik a piac hatékonyságát, de jelentős mértékben csökkentik a bizonytalanságot is.

\section{Arrow válasza a kritikákra²}

Az 1963 -as cikk, amely az egészségügy piacán észlelhető bizonytalanságokról szólt, Arrow egyik legidézettebb cikke, és az egészségügy közgazdaságtanának az egyik kiindulópontja lett. Sokan egyetértettek a cikk állításaival, de idővel sok kritika is megjelent, amelyekre Arrow egy 2001-es cikkben válaszolt öt pontba szedve az érveit. Az eredeti cikk fö állítása az volt, hogy az egészségügyben jelentkező nagyfokú bizonytalanság, illetve a páciens és az orvos közötti információs aszimmetria hívta életre azokat a társadalmi intézményeket, melyek megakadályozzák a hatékony piac kialakulását.

\section{A költségek megnövekedésének oka a technológiai fejlődés.}

Az első jelenség, amelyre Arrow reflektál, a megugró egészségügyi költésekre vonatkozik. Míg az eredeti cikk megjelenésekor az USA GDP-jének 4 százalékát költötte az egészségügyre, 2001-re ez a szám 14 százalékra nőtt. Ez szerinte egybevág az ő eredeti állításaival is. Az egyik oka a költségek megnövekedésének az, hogy elterjedtebbek lettek a szabad intézményválasztást lehetővé tévő biztosítások, és erről a konstrukcióról már 
az eredeti cikkben is leírta, hogy egyszerüen nincsen jelen benne az a mechanizmus, amely költségcsökkentésre ösztönözné a szereplőket.

A költségek megnövekedésének a másik oka pedig a technológiai fejlődés. Ez ellentmondásosnak tűnik elsőre, ugyanis a technológia fejlődése jellemzően alacsonyabb költségeket szokott eredményezni, de szerinte itt egy másik mechanizmus figyelhető meg. Mivel a fejlettebb technológia ezen a piacon a kezelés kimenetének a bizonytalanságát csökkenti, a fogyasztók hajlandóak jelentősen többet fizetni ezekért az új kezelésekért, és így a bizonytalanság csökkentésébe hatalmas összegeket tudott befektetni a társadalom, ami megnövelte a szolgáltatás árát is

Az eredeti cikk keletkezése óta sokat változott az amerikai egészségügy, és ezért Arrow-nak felül kellett bírálnia az eredeti cikkének azt az állítását, hogy az orvosok szükségszerűen nem üzletemberként viselkednek. Megjelentek a reklámok és a profitorientált kórházak, amelyek néha tőkepiacokon aktívan kereskedett kötvényekkel finanszírozzák magukat, és ez hatással van az egész egészségügyre.

A legtöbbet vitatott része a '63-as cikknek a versenyt korlátozó társadalmi intézmények szükségszerüsége volt. Több kritikus felvetette, hogy a kisebb belépési korlátok mellett is ugyanott lenne az egyensúlyi állapot, az orvosláshoz nem értő, tehát rossz szolgáltatást nyújtó szereplők úgyis kikopnának a piacról. Arrow viszont kitart amellett, hogy a magas belépési korlátok csökkentik a bizonytalanságot, és ezért ezek a társadalmi intézmények önmagukban is jólétet növelnek.

Vannak, akik azt mondják, hogy ezzel csak az orvosok próbálják a versenyt csökkenteni, és kihasználják a társadalmi helyzetüket, de Arrow szerint erre semmi jel nem utal. Egyrészt még sosem volt olyan döntése az orvosi kamarának, amely a profitmaximalizálást segítené, illetve a társadalomban egyszerủen nincsen akkora alkuerejük az orvosoknak, amivel visszaélhetnének. Ha a belépési korlátok indokolatlanul magasak volnának, könnyen lenne politikai akarat a megváltoztatásukra

Az eredeti cikk óta eltelt időben beköszöntött az információs forradalom, és ez hatással lesz az egészségügyben tapasztalható bizonytalanságra is. Arrow elismeri, hogy ez hosszú távon a most ismert társadalmi intézmények megváltozásához vezethet, de szerinte a társadalom még nem találta meg a módját, hogy éljen ezzel a lehetőséggel, és ezért szerinte az internet korában is megmaradnak még hosszú ideig az általa felvázolt társadalmi intézmények

A cikk utolsó reflexiója a legspekulatívabb, ahol arra próbál választ találni a szerző, hogy ha ennyire hasonló és szükségszerủ jellemzői vannak a piacnak mindenhol a világon, miért létezhetnek ennyire különböző egészségügyi rendszerek a különböző országokban? Szerinte ennek oka az, hogy egy olyan komplex és útvonalfüggő rendszerről van szó, amelyben egy apróbb kezdeti eltérés is jelentős különbségekhez vezethet hosszú távon.

Példaként említi a vállalatfinanszírozást, amelynek minden piacgazdaságban hasonló problémákat kell megoldania, mégis az angolszász országokban a tőkepiacokon keresztül, részvényekkel és kötvényekkel finanszírozzák a legtöbb vállalatot, Európában pedig jellemzőbbek a bankhitelek. Ez az útvonalfüggőség ad olyan tehetetlenséget bizonyos társadalmi rendszereknek, ami egy idő után egészen különböző válaszokat eredményez hasonló problémákra, és ez teszi különbözővé az egészségügyet a világ különböző tájain.

\section{A levonásos biztosításokról általában}

Az 1963-as egészségügyről szóló cikk után Arrow tovább foglalkozott a témával, és 1973-ban az Office of Economic Opportunity megbízásából cikket írt az optimális biztosításokról, amely az Optimal Insurance and Generalized Deductibles címet kapta. Bár a cikk fö célja az optimális egészségbiztosítási struktúra megtalálása, a biztosításválasztásról általában beszél szigorúan mikroökonómiai keretek között.

\section{A biztosított csak az önrész mértékét fizeti, ez Amerikában} jellemző struktúrája az egészségbiztosításnak.

A cikkben vizsgált biztosítástípust angolul a deductibles szóval illeti, ami az olyan biztosításokat jelöli, ahol egy bizonyos szintig a biztosított viseli a terheket, az önrész elérése után pedig a biztosított csak az önrész mértékét fizeti, a kár növekedését teljes egészében a biztosító állja. Ez Amerikában jellemző struktúrája az egészségbiztosításnak. A cikk fogalomrendszerében maga a biztosítási esemény jövedelemkiesés, amit egy bizonyos szinten felül pótol a biztosítás a folyamatos díjfizetés fejében.

Arrow itt is megjegyzi, hogy az emberek egészségbiztosítását nehéz modellezni, ugyanis az egészségkárosodás okozta hasznosságkiesést nem lehet feltétlenül pénzben pótolni, továbbá az emberek hasznossági függvénye időben változhat az állapotuk változásával. Ennek feloldására szolgál, hogy csak a jövedelemkiesés (ami értelmezhető orvosi költségként is) kerül pótlásra a biztosítás által, az állapotfüggő hasznosságfüggvényeket viszont a cikkben megengedi.

\section{Optimális biztosítás világállapottól független hasznosságfüggvények esetén}

A vizsgált modellben a biztosító kockázatsemleges, tehát a biztosítási díj a kifizetések várható értékének és az adminisztrációs költségeknek az összege. A biztosítottak ezzel szemben kockázatkerülők, tehát a jövedelemre vonatkozó hasznosságfüggvényük minden pontban konkáv, másképp kifejezve egy fix kifizetés és egy ugyanolyan várható értékű, de bizonytalan kifizetés közül a fix összeget választják.

A modellben felteszi, hogy a különböző világállapotok $s=1,2,3, \ldots N$ sorszámmal vannak jelölve, ezek közül pedig az $S$ halmazba tartozó világállapotok jelölik a biztosítási eseményt, tehát amikor a jövedelemkiesés a kritikus szint felett van. 


\section{A modellben az alábbi változókat használja:}

as $=$ az adott világállapotbeli jövedelem biztositás nélkül ys = az adott világállapotbeli jövedelem biztositás mellett

Us $(y s)=$ adott világállapotbeli hasznossága a biztositottnak

$p s=a z$ adott világállapot bekövetkezésének valószinüsége

is $=$ a biztositás kifizetése az adott világállapotban

$P=$ biztositási díj, amit minden világállapotban fizet a biztosított

$E=a$ biztositás kifizetésének várható értéke

$\alpha=E / P$

Az adott világállapotban a felhasználható jövedelem tehát az endogén jövedelemből, a díjfizetésből és az esetleges biztosítási kifizetésből áll:

$$
y_{s}=a_{s}+i_{s}-P
$$

A várható érték pedig értelemszerűen a következő egyenletből adódik:

$$
E=\sum_{s} p_{s} i_{s}
$$

A biztosítási kifizetések nem negatívak, tehát:

$$
0 \leq i_{s}
$$

A fizetett díj mindenképpen fedezi a kifizetések várható értékét, illetve az esetleges adminisztratív költségeket:

$$
0 \leq \alpha \leq 1
$$

Tudjuk továbbá, hogy a hasznossági függvény konkáv minden jövedelmi szintre minden világállapotban:

$$
U_{s}^{\prime \prime}\left(y_{s}\right)<0
$$

A megoldandó probléma tehát ezen korlátozó feltételek mentén maximalizálni az alábbi egyenletet:

$$
\sum_{s} p_{s} u_{s}\left(y_{s}\right)
$$

Az első esetben feltételezzük, hogy a hasznosságfüggvények függetlenek a világállapotoktól, és így a megoldandó egyenlet a következőképp egyszerűsödik:

$$
\sum_{s} p_{s} U\left(y_{s}\right)=\sum_{s} p_{s} U\left(a_{s}+i_{s}-P\right)
$$

Arrow az $E$ és $P$ paramétereket fixnek tekinti itt, és keresi a biztosítási események azon $S$ halmazát a hozzájuk tartozó kifizetésekkel, ami maximalizálja a biztosított hasznosságát. A maximalizáláshoz a Kuhn-Tucker módszert alkalmazza, amiből adódik egy olyan $\lambda$ határhasznosság, amely alatti értékekre a biztosítást megkötik. A biztosítási események $S$ halmaza tehát a következő:

$$
S=\left\{s \mid U^{\prime}\left(a_{s}+i_{s}-P\right)=\lambda\right\}
$$

Tehát ahol a kritikus szint fölé nőne a határhaszon, ott pótolná ki a biztosítás a jövedelmet, és mivel a hasznosságfüggvények állapotfüggetlenek, ez a bizonyos szint minden világállapotban azonos jövedelemszinten adódna a következő egyenlet szerint:

$$
\bar{a}=\left(\sum_{s \in S} p_{s} a_{s}+E\right) / p(S)
$$

A $p(S)$ jelölés értelemszerűen az $S$ eseményhalmaz, tehát a biztosítási esemény bekövetkezésének valószínűségét jelöli. Érdemes megfigyelni, hogy a végső megoldásban nem szerepel a hasznosságfüggvény, az egyetlen paraméter az E. Ez határozza meg, hogy a világállapotok mekkora halmazára tud az egyén biztosítást kötni, és a hasznosságfüggvény csak az ehhez a szinthez kapcsolódó hasznosságot határozza meg, de nem okoz választásbeli különbséget.

\section{Optimális biztosítás világállapottól függő hasznosságfüggvények esetén}

Az első modellt követően Arrow megvizsgálja, hogy milyen megállapításokat tehetünk, ha megengedjük, hogy világállapotonként különböző hasznossági függvénye legyen a biztosítottaknak. A modell minden más eleme változatlan, egyedül a hasznosságfüggvényekre vonatkozó korlátozás változik, minden világállapothoz külön hasznossági függvény tartozik. Ekkor az optimalizálandó függvény a következő alakot ölti:

$$
\sum_{s} p_{s} U_{s}\left(a_{s}+i_{s}-P\right)
$$

Az optimalizálás itt is hasonlóképpen folyik, és az előző modellhez hasonló képletet kapunk a biztosítási események halmazának meghatározásakor: 
A $\lambda$ itt szintén a kritikus maximális határhasznosságot jelöli, tehát a biztosítás megint egy bizonyos hasznossági szint alatt fog életbe lépni, és pótolja ki egy adott szintig a jövedelmet. A legfőbb különbség, hogy amíg az előző esetben ezt egy globális jövedelmi szint is jellemezte, ebben az esetben az állapotfüggő hasznosságfüggvények miatt ilyen állítást nem tehetünk. Az optimális jövedelmi szint, amely alatt életbe lép a biztosítás, hasznossági függvényenként így állapotonként különbözik.

\section{Komparatív statika az optimális biztosításokra}

A cikk további részeiben Arrow azzal foglalkozik, hogy az egyes paraméterek megváltoztatása hogyan befolyásolja az egyensúlyi állapotot. A megállapításokat illetően a megengedőbb eset fogalmait használja, tehát a biztosítási szintet a kritikus határhasznosság jellemzi, ami az egységes hasznosságfüggvények esetében egy kritikus jövedelemszinttel is párosul.

Az első feloldott feltétel az eddig fix biztosítási dijira és várható kifizetésre vonatkozik. A modell alapján Arrow igazolja az intuitíve várható eredményt, miszerint magasabb várható kifizetés csökkenti a kritikus határhasznosságot, míg a magasabb díj növeli azt ceteris paribus. A kifizetés per díj $(\alpha)$ mutató növekedése pedig olyan módon változtatja meg a biztosított világállapotok halmazát, hogy korábban nem biztosított világállapotok is biztosítottá válnak.

A világállapotokban megjelenő endogén jövedelmek változását illetően Arrow megállapítja, hogy bármely világállapotbeli jövedelem növekedése csökkenti a kritikus határhasznosságot, míg a valószínűségeket illetően csak igen komplex megállapításokat tesz, de általánosságban elmondható, hogy a biztosított kimenetek valószínűségének a növekedése növeli a kritikus határhasznosságot.

\section{Összefoglalás}

Ahogy az a bevezetőben is említésre került, Kenneth J. Arrow munkássága olyan széles körű, hogy csak a biztosítási relevanciával bíró szeletét is kihívás lenne egyetlen írásban bemutatni, a feldolgozott három cikk éppen csak betekintést enged nyerni munkásságába. Az 1963-as cikk általános érvényü megállapításokat tesz az egészségügy piaci mechanizmusait illetően, amelyek eddig sikeresen állták ki az idő próbáját. Ezt foglalta össze a 2001-es reflexió, amelyben Arrow az eredeti cikk állításaival tudott alátámasztani azóta bekövetkezett eseményeket. A harmadik cikk pedig mikroökonómiai érvrendszerrel vezette le az optimális biztosítási struktúrát

Kenneth J. Arrow korának egyértelműen egyik legnagyobb hatású közgazdásza volt, munkássága önálló közgazdaság-tudományi területeket indított útjára, illetve régóta kutatott kérdéskörökben sikerült újat alkotnia. Az egészségbiztosítás a kettő határán van, bár sokan foglalkoztak már előtte biztosítási kérdésekkel, ő mégis újat tudott mutatni, az egészségügy közgazdaságtanának pedig az egyik alapművét alkotta meg, és ezzel a biztosítások területén is örökre beírta nevét a szakma történelemkönyvébe.

\section{HIVATKOZÁSOK}

${ }^{1}$ Arrow 1963-as cikkén alapul ez az ismertetés.

${ }^{2}$ Ezek a válaszok Arrow (2001)-es írásában olvashatóak.

${ }^{3}$ Ez a rész Arrow (1973) cikkén alapul.

\section{IRODALOMJEGYZÉK}

Csekő Imre (2017): Kenneth J. Arrow

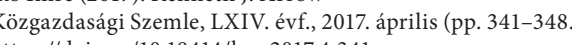
Michael M. Weinstein (2017): Kenneth Arrow

The New York Times, 2017. február 21. https://www.nytimes.com/201/12/21/business/economy/kenneth-arrow-dead-nobel-laureate-in-economics.html (letöltve: 2017.05.03.) Kenneth J. Arrow (1963): Uncertainty and the Welfare Economics of Medical Care

Kenneth I. Arrow (2001): Reflections on the Reflections

Journal of Health Politics Policy and Law 2001 (pp. 1197-1203) https://doi.org/10.1215/03616878-26-5-1197

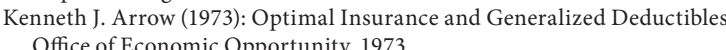

